\title{
Comparison of Dimensional Accuracy of Cast Obtained from Polyvinyl Siloxane Impression with Different Putty- Wash Techniques and Spacer Thickness - In Vitro Study
}

\author{
Pandey $\mathrm{A}^{1^{*}}$, Mathema $\mathrm{SRB}^{2}$, Maharjan $\mathrm{SK}^{3}$ \\ ${ }^{1}$ Lecturer, Department of Prosthodontics and Maxillofacial Prosthetics, \\ College of Medical Science, Bharatpur, Chitwan, Nepal \\ ${ }^{2}$ Professor, ${ }^{3}$ Assistant Professor, Department of Prosthodontics and Maxillofacial Prosthetics, \\ People's Dental College and Hospital, Shorakhutte, Kathmandu, Nepal.
}

\begin{abstract}
Introduction: Dimensional accuracy of cast obtained after making impressions is crucial factor for the quality of fixed prosthodontic treatment. The impression technique with different thickness of putty wash material is critical factor affecting this accuracy. There is much discussion in the dental literature concerning the effect of this impression technique on the accuracy of cast restorations.

Materials and methods: This in- vitro study was carried out in 60 impression made from master model with Polyvinyl siloxane impressions material using single step putty- wash technique and two step putty-wash technique with varying spacer thickness $(0.5 \mathrm{~mm}, 1 \mathrm{~mm}, 1.5 \mathrm{~mm})$. It was further divided into four groups. Group I: Single step putty-wash impression technique, Group II: Two step putty- wash impression technique with $0.5 \mathrm{~mm}$ spacer, Group III: Two step putty- wash impression technique with $1 \mathrm{~mm}$ spacer, Group IV: Two step putty- wash impression technique with $1.5 \mathrm{~mm}$ spacer. Each group consists of 15 impressions. Casts were poured using type IV dental stone after 1 hour. After 24 hour the die of each cast was scanned using CAD/CAM digital scanner and measured mesiodistally, facio-lingually, height (cervico- occlusally), interabutment or interdie distances. The data were recorded and statically analyzed.

Results: The highest mean values of mesio-distal, bucco-lingual, cervico-occlusal distances were shown by Group I, whereas the inter-die distance showed equal mean value in Group I, II and III. With the increase in the spacer thickness, the mean value also increases in mesio-distal distance. The mean measurement of bucco-lingual dimension was highest when spacer thickness was $0.5 \mathrm{~mm}$ and it declined with the increase in spacer thickness. The spacer thickness had no effect on cervico-occlusal and inter-die dimensions.

Conclusions: Within the limitations of the study, accuracy of cast obtained from single step putty-wash technique was more accurate than two step putty-wash technique. In two step putty-wash technique, $1.5 \mathrm{~mm}$ thickness of spacer showed more accurate cast in comparison to $0.5 \mathrm{~mm}$ and $1 \mathrm{~mm}$.
\end{abstract}

Key words: Dimensional accuracy, Die, Putty- wash technique, Spacer thickness

\section{Introduction}

$\mathrm{F}$ abrication of a well fitted indirect restorations requires accurate casts of

\section{*Corresponding Author}

Dr. Anisha Pandey, Lecturer

Department of Prosthodontics and Maxillofacial

Prosthetics, College of Medical Science, Bharatpur,

Chitwan, Nepal

E-mail:anisha.reakeey@gmail.com intraoral hard and oral soft tissues. ${ }^{1}$ Undistorted impressions of the prepared tooth is necessary which can be obtained only when there is thorough knowledge of impression materials, their properties, and manipulation techniques. ${ }^{2}$

Besides the selection of appropriate impression materials and trays, impression technique also plays a vital role for obtaining best dimensional accuracy. Among several techniques to improve 
the accuracy of the cast, putty-wash techniques are most commonly used. Single step puttywash technique and two step putty-wash techniques with spacer are generally practiced with putty and light body elastomers. ${ }^{3}$

Although several studies regarding the efficacy of accuracy of cast obtained from different impression techniques has been conducted, there is lack of sufficient information of the impact of spacer thickness on accuracy of cast. Hence this study was conducted to evaluate and compare the accuracy of cast obtained from single and double step polyvinyl siloxane puttywash impression technique with $0.5 \mathrm{~mm}, 1 \mathrm{~mm}$, and $1.5 \mathrm{~mm}$ spacer thickness.

\section{Materials and methods}

According to American National Standards Institute (ANSI)/American Dental Association (ADA) specification brass master model containing two complete crown abutments of stainless steel were fabricated. Dimension of occluso-gingival length of abutments of master model was $8 \mathrm{~mm}$, width was $6.25 \mathrm{~mm}$ and the base was $2 \mathrm{~mm}$ in height with total taper of 6 degree. Cross grooves were provided on the occlusal surfaces of $1 \mathrm{~mm}$ in depth to serve as reference points for making measurements. The distance between two dies was $21.5 \mathrm{~mm}$. (Fig.1) Perforated brass trays were fabricated maintaining a space of $7 \mathrm{~mm}$ and holes of 2 $\mathrm{mm}$ in diameter for mechanical retention of the impression material. (Fig.2) Brass Spacers were also fabricated of $0.5 \mathrm{~mm}, 1 \mathrm{~mm}$ and $1.5 \mathrm{~mm}$ in thickness (Fig.3). Impressions were made accordingly:

Group I - Single step putty- wash impression technique:

Putty consistency polyvinyl siloxane impression material (Aquasil, Dentsply) was mixed as per manufacturer's instructions and loaded on the impression tray. Light body (Aquasil Ultra XLV,
Dentsply) was dispensed from auto mixing cartridge and injected over the abutment. Impression tray was pressed gently with finger to establish metal to metal contact.

Group II - Two step putty- wash impression technique with $0.5 \mathrm{~mm}$ spacer:

Putty consistency polyvinyl siloxane impression material was mixed and loaded on the tray which was pressed over the abutment with $0.5 \mathrm{~mm}$ spacer until metal to metal contact was established. After setting of the elastomeric impression material spacer was removed and light body elastomer was dispensed from auto mixing cartridge over the abutments and on the tray with putty. The tray was reseated and gentle pressure was applied with finger to establish metal to metal contact.

Group III - Two step putty- wash impression technique with $1 \mathrm{~mm}$ spacer:

Impression procedure was similar to that done for Group II with the spacer of $1 \mathrm{~mm}$ thickness.

Group IV - Two step putty- wash impression technique with $1.5 \mathrm{~mm}$ spacer:

Impression procedure was similar to that done for Group II with the spacer of $1.5 \mathrm{~mm}$ thickness.

All the impressions were poured after half an hour of impression making with type IV Dental stone mixed in the ratio of $22 \mathrm{ml}$ of water: $100 \mathrm{gm}$ of die stone which were allowed to set for 1 hour before retrieval of the dies. After 24 hour each die was scanned in 3D Scanner. Measurements were made in facio-lingual, mesio-distal, cervico-occlusal and inter-die dimensions of abutment respectively for three times. Master Model was scanned in 3D Scanner and the measurements were recorded 10 times.

Mean of the repeated measurements were recorded and entered in Microsoft Excel to reduce the error. The data was cleaned and coded. It was then transferred to Statistical 
Package of Social Sciences (SPSS) version 17.0 for further analysis. The data was displayed with the help of simple and component bar diagrams, line diagrams and frequency distribution tables. Comparisons of various dimensions of dies in the study groups were made with in the control (master die). Comparisons of diagnostic accuracy between the single tray and the double tray technique and between three different spacer thicknesses were also made. One Way Analysis of Variance (ANOVA) with Benferroni post hoc tests were used to check for the level of significance which was set at $5 \%$.

\section{Results}

The highest mean values of mesio-distal, bucco-lingual, cervico-occlusal was shown by Group I whereas the inter-die distance showed equal mean value in Group I, II and III. While in single and two step impression technique the highest mean difference of mesio-distal dimension was seen in Group I and Group IV. (Table 1) The highest mean difference of buccolingual dimension was in Group I and Group II. (Table 2) In cervico-occlusal dimension the mean difference failed to reach statical significance i.e. $p>0.05$ indicating any technique can be used for recording this measurement. (Table 3) Similarly inter-die dimension also showed impression technique have no role in its measurement. (Table 4)

Comparing within two step impression technique with $0.5 \mathrm{~mm}, 1 \mathrm{~mm}, 1.5 \mathrm{~mm}$ spacer showed that as the spacer thickness increases, the mean measurement also increases in mesio-distal measurement. (Table 5) The mean measurement of bucco-lingual dimension is highest when spacer thickness is $0.5 \mathrm{~mm}$ and it starts to decline as spacer thickness increases. (Table 6) Measuring cervico-occlusal and inter-die dimension have no effect on spacer thickness. (Table 7 and 8)

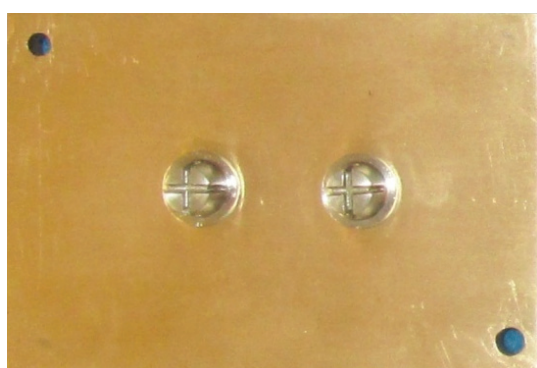

Figure 1: Master Die

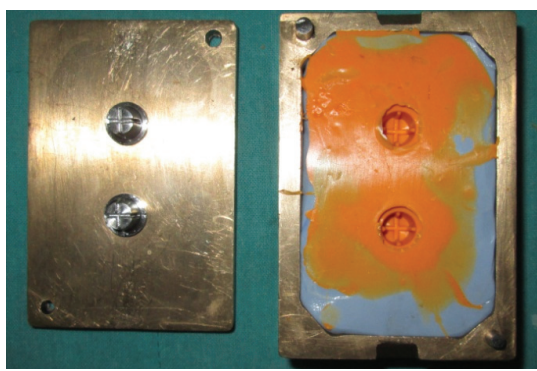

Figure 4: Putty-wash impression

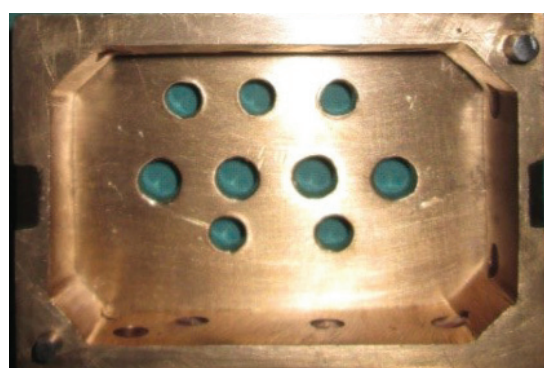

Figure 2: Customarily made tray

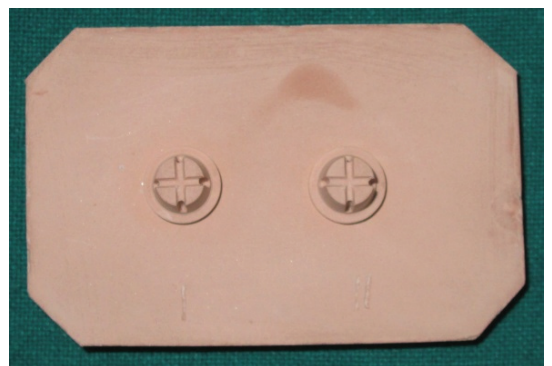

Figure 5: Die

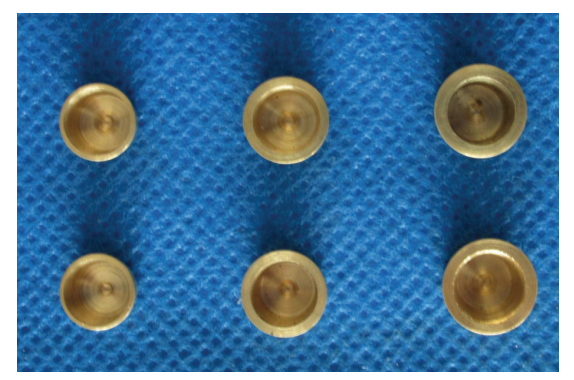

Figure 3: Spacers

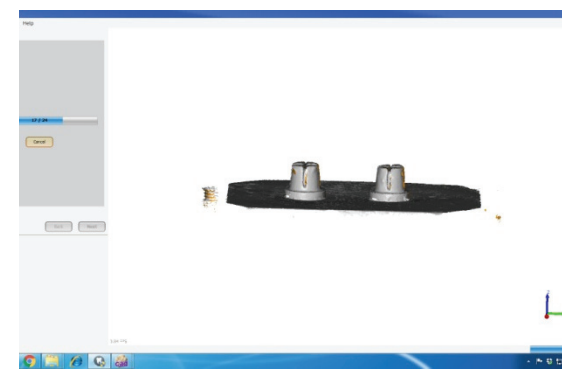

Figure 6: 3D Image on monitor 
Table 1: Variations in the measurement of mesio-distal dimensions (AB, CD) between the single and double tray technique.

\begin{tabular}{|c|c|c|c|c|c|}
\hline \multirow{2}{*}{ Mesio-distal dimensions } & \multirow{2}{*}{ Comparison Group } & \multirow{2}{*}{ Mean Diff } & \multicolumn{2}{|c|}{$95 \%$ confidence interval } & \multirow{2}{*}{ P value } \\
\hline & & & Lower & Upper & \\
\hline \multirow{3}{*}{$\begin{array}{c}\text { AB dimension when using } \\
\text { single tray technique } \\
(4.89 \pm 0.05)\end{array}$} & $\begin{array}{c}\text { Group II } \\
(4.73 \pm 0.10)\end{array}$ & 0.159 & 0.088 & 0.230 & $<0.001 *$ \\
\hline & $\begin{array}{c}\text { Group III } \\
(4.76 \pm 0.15)\end{array}$ & 0.137 & 0.066 & 0.208 & $<0.001 *$ \\
\hline & $\begin{array}{c}\text { Group IV } \\
(4.81 \pm 0.08)\end{array}$ & 0.086 & 0.015 & 0.157 & $0.017^{*}$ \\
\hline \multirow{3}{*}{$\begin{array}{c}\mathrm{CD} \text { dimension when using } \\
\text { single tray technique } \\
(4.88 \pm 0.05)\end{array}$} & $\begin{array}{c}\text { Group II } \\
(4.74 \pm 0.11)\end{array}$ & 0.143 & 0.075 & 0.212 & $<0.001 *$ \\
\hline & $\begin{array}{c}\text { Group III } \\
(4.71 \pm 0.11)\end{array}$ & 0.171 & 0.103 & 0.240 & $<0.001$ \\
\hline & $\begin{array}{c}\text { Group IV } \\
(4.75 \pm 0.11)\end{array}$ & 0.127 & 0.058 & 0.195 & $<0.001$ \\
\hline
\end{tabular}

*Statistically significant.

Table 2: Variations in the measurement of bucco-lingual dimensions (EF, GH) between the single and double tray technique.

\begin{tabular}{|c|c|c|c|c|c|}
\hline \multirow{2}{*}{ Bucco -lingual dimensions } & \multirow{2}{*}{ Comparison Group } & \multirow{2}{*}{ Mean Diff } & \multicolumn{2}{|c|}{ 95\% confidence interval } & \multirow{2}{*}{ P value } \\
\hline & & & Lower & Upper & \\
\hline \multirow{3}{*}{$\begin{array}{c}\text { EF dimension when using } \\
\text { single tray technique } \\
(4.68 \pm 0.06)\end{array}$} & $\begin{array}{c}\text { Group II } \\
(4.68 \pm 0.06)\end{array}$ & 0.163 & 0.099 & 0.227 & $<0.001 *$ \\
\hline & $\begin{array}{c}\text { Group III } \\
(4.52 \pm 0.10)\end{array}$ & 0.143 & 0.079 & 0.207 & $<0.001^{*}$ \\
\hline & $\begin{array}{c}\text { Group IV } \\
(4.54 \pm 0.10)\end{array}$ & 0.098 & 0.034 & 0.162 & $0.003 *$ \\
\hline \multirow{3}{*}{$\begin{array}{c}\text { GH dimension when using } \\
\text { single tray technique } \\
(4.74 \pm 0.04)\end{array}$} & $\begin{array}{c}\text { Group II } \\
(4.56 \pm 0.10)\end{array}$ & 0.180 & 0.113 & 0.247 & $<0.001 *$ \\
\hline & $\begin{array}{c}\text { Group III } \\
(4.60 \pm 0.09)\end{array}$ & 0.143 & 0.075 & 0.210 & $<0.001 *$ \\
\hline & $\begin{array}{c}\text { Group IV } \\
(4.65 \pm 0.12)\end{array}$ & 0.086 & 0.019 & 0.153 & $0.013^{*}$ \\
\hline
\end{tabular}

*Statistically significant.

Table 3: Variations in the measurement of cervico -occlusal dimensions (EI, GJ) between the single and double tray technique.

\begin{tabular}{|c|c|c|c|c|c|}
\hline $\begin{array}{c}\text { Cervico - occlusal } \\
\text { dimensions }\end{array}$ & Comparison Group & Mean Diff & \multicolumn{3}{|c|}{$\mathbf{9 5 \%}$ confidence interval } \\
\hline
\end{tabular}




\begin{tabular}{|c|c|c|c|c|c|}
\hline \multirow{3}{*}{$\begin{array}{l}\text { GJ dimension when using } \\
\text { single tray technique } \\
(5.74 \pm 0.06)\end{array}$} & $\begin{array}{c}\text { Group II } \\
(4.88 \pm 0.05)\end{array}$ & 0.405 & -0.097 & 0.907 & 0.112 \\
\hline & $\begin{array}{c}\text { Group III } \\
(4.74 \pm 0.11)\end{array}$ & 0.067 & -0.435 & 0.570 & 0.789 \\
\hline & $\begin{array}{c}\text { Group IV } \\
(4.71 \pm 0.11)\end{array}$ & 0.074 & -0.427 & 0.577 & 0.767 \\
\hline
\end{tabular}

*Statistically significant.

Table 4: Variations in the measurement of inter die distance (KL) between the single and double tray technique.

\begin{tabular}{|c|c|c|c|c|c|}
\hline \multirow{2}{*}{ Inter-die distance } & \multirow{2}{*}{ Comparison Group } & \multirow{2}{*}{ Mean Diff } & \multicolumn{2}{|c|}{$95 \%$ confidence interval } & \multirow{2}{*}{ P value } \\
\hline & & & Lower & Upper & \\
\hline \multirow{3}{*}{$\begin{array}{c}\text { KL dimension when using } \\
\text { single tray technique } \\
(21.41 \pm 0.02)\end{array}$} & $\begin{array}{c}\text { Group II } \\
(21.40 \pm 0.08)\end{array}$ & 0.012 & -0.039 & 0.065 & 0.626 \\
\hline & $\begin{array}{c}\text { Group III } \\
(21.39 \pm 0.07)\end{array}$ & 0.018 & -0.034 & 0.070 & 0.498 \\
\hline & $\begin{array}{c}\text { Group IV } \\
(21.41 \pm 0.08)\end{array}$ & 0.004 & -0.048 & 0.057 & 0.873 \\
\hline
\end{tabular}

Table 5: Variations in the measurement of mesio-distal dimensions (AB, CD) when using $0.5 \mathrm{~mm}$, $1 \mathrm{~mm}, 1.5 \mathrm{~mm}$ spacers.

\begin{tabular}{|c|c|c|c|c|c|}
\hline \multirow{2}{*}{ Mesio-distal dimensions } & \multirow{2}{*}{ Comparison Group } & \multirow{2}{*}{ Mean Diff } & \multicolumn{2}{|c|}{ 95\% Confidence Interval } & \multirow{2}{*}{ P value } \\
\hline & & & Lower & Upper & \\
\hline \multirow{2}{*}{$\begin{array}{c}\text { AB dimension when using } \\
0.5 \mathrm{~mm} \text { spacer (Group II) } \\
(4.73 \pm 0.10)\end{array}$} & $\begin{array}{l}\text { Group III }(1 \mathrm{~mm}) \\
(4.76 \pm 0.15)\end{array}$ & -0.021 & -0.092 & 0.049 & 0.544 \\
\hline & $\begin{array}{l}\text { Group IV }(1.5 \mathrm{~mm}) \\
\quad(4.81 \pm 0.08)\end{array}$ & -0.072 & -0.143 & -0.001 & $0.046^{*}$ \\
\hline $\begin{array}{l}\text { Group III (1mm) } \\
\quad(4.76 \pm 0.15)\end{array}$ & $\begin{array}{l}\text { Group IV }(1.5 \mathrm{~mm}) \\
\quad(4.81 \pm 0.08)\end{array}$ & -0.050 & -0.121 & 0.020 & 0.159 \\
\hline \multirow{2}{*}{$\begin{array}{c}\text { CD dimension when using } \\
0.5 \mathrm{~mm} \text { spacer (Group II) } \\
(4.73 \pm 0.10)\end{array}$} & $\begin{array}{l}\text { Group III }(1 \mathrm{~mm}) \\
\quad(4.76 \pm 0.15)\end{array}$ & 0.028 & -0.040 & 0.096 & 0.415 \\
\hline & $\begin{array}{l}\text { Group IV }(1.5 \mathrm{~mm}) \\
\quad(4.81 \pm 0.08)\end{array}$ & -0.016 & -0.085 & 0.051 & 0.631 \\
\hline $\begin{array}{l}\text { Group III (1mm) } \\
\quad(4.76 \pm 0.15)\end{array}$ & $\begin{array}{l}\text { Group IV }(1.5 \mathrm{~mm}) \\
\quad(4.81 \pm 0.08)\end{array}$ & -0.044 & -0.113 & 0.023 & 0.197 \\
\hline
\end{tabular}

*statistically significant.

Table 6: Variations in the measurement of bucco-lingual dimensions (EF, GH) when using $0.5 \mathrm{~mm}$, $1 \mathrm{~mm}, 1.5 \mathrm{~mm}$ spacers.

\begin{tabular}{|c|c|c|c|c|c|}
\hline \multirow{2}{*}{ Bucco -lingual dimensions } & \multirow{2}{*}{ Comparison Group } & \multirow{2}{*}{ Mean Diff } & \multicolumn{2}{|c|}{$95 \%$ confidence interval } & \multirow{2}{*}{ P value } \\
\hline & & & Lower & Upper & \\
\hline \multirow{2}{*}{$\begin{array}{c}\text { EF dimension when using } \\
0.5 \mathrm{~mm} \text { spacer (Group II) } \\
(4.68 \pm 0.06)\end{array}$} & $\begin{array}{l}\text { Group III ( } 1 \mathrm{~mm}) \\
\quad(4.52 \pm 0.10)\end{array}$ & -0.020 & -0.084 & 0.043 & 0.5300 \\
\hline & $\begin{array}{l}\text { Group IV }(1.5 \mathrm{~mm}) \\
\quad(4.54 \pm 0.10)\end{array}$ & -0.065 & -0.129 & -0.001 & $0.045^{*}$ \\
\hline $\begin{array}{l}\text { Group III }(1 \mathrm{~mm}) \\
\quad(4.52 \pm 0.10)\end{array}$ & $\begin{array}{l}\text { Group IV }(1.5 \mathrm{~mm}) \\
\quad(4.54 \pm 0.10)\end{array}$ & -0.045 & -0.108 & 0.018 & 0.164 \\
\hline
\end{tabular}




\begin{tabular}{|c|c|c|c|c|c|}
\hline $\begin{array}{c}\text { GH dimension when using } \\
0.5 \mathrm{~mm} \text { spacer (Group II) } \\
(4.56 \pm 0.10)\end{array}$ & $\begin{array}{c}\text { Group III (1mm) } \\
(4.60 \pm 0.09)\end{array}$ & -0.037 & -0.104 & 0.029 & 0.271 \\
\hline $\begin{array}{c}\text { Group IV (1.5mm) } \\
(4.65 \pm 0.12)\end{array}$ & -0.094 & -0.161 & -0.027 & $0.007^{*}$ \\
\hline $\begin{array}{c}\text { Group III (1mm) } \\
(4.60 \pm 0.09)\end{array}$ & $\begin{array}{c}\text { Group IV (1.5mm) } \\
(4.65 \pm 0.12)\end{array}$ & -0.057 & -0.124 & 0.010 & 0.095 \\
\hline
\end{tabular}

*statistically significant

Table 7: Variations in the measurement of cervico -occlusal dimensions (EI, GJ) when using 0.5mm, $1 \mathrm{~mm}, 1.5 \mathrm{~mm}$ spacers.

\begin{tabular}{|c|c|c|c|c|c|}
\hline \multirow{2}{*}{$\begin{array}{c}\text { Cervico - occlusal } \\
\text { dimensions }\end{array}$} & \multirow{2}{*}{ Comparison Group } & \multirow{2}{*}{ Mean Diff } & \multicolumn{2}{|c|}{$95 \%$ confidence interval } & \multirow{2}{*}{ P value } \\
\hline & & & Lower & Upper & \\
\hline \multirow{2}{*}{$\begin{array}{l}\text { EI dimension when using } \\
0.5 \mathrm{~mm} \text { spacer (Group II) } \\
(5.69 \pm 0.81)\end{array}$} & $\begin{array}{c}\text { Group III } \\
(5.73 \pm 0.08)\end{array}$ & -0.045 & -0.099 & 0.009 & 0.101 \\
\hline & $\begin{array}{c}\text { Group IV } \\
(5.70 \pm 0.05)\end{array}$ & -0.019 & -0.073 & 0.034 & 0.478 \\
\hline $\begin{array}{c}\text { Group III } \\
(5.73 \pm 0.08)\end{array}$ & $\begin{array}{c}\text { Group IV } \\
(5.70 \pm 0.05)\end{array}$ & 0.025 & -0.028 & 0.080 & 0.346 \\
\hline \multirow{2}{*}{$\begin{array}{c}\text { GJ dimension when using } \\
0.5 \mathrm{~mm} \text { spacer (Group II) } \\
(4.88 \pm 0.05)\end{array}$} & $\begin{array}{c}\text { Group III } \\
(4.74 \pm 0.11)\end{array}$ & -0.337 & -0.840 & 0.165 & 0.184 \\
\hline & $\begin{array}{c}\text { Group IV } \\
(4.71 \pm 0.11)\end{array}$ & -0.330 & -0.833 & 0.172 & 0.194 \\
\hline $\begin{array}{c}\text { Group III } \\
(4.74 \pm 0.11)\end{array}$ & $\begin{array}{c}\text { Group IV } \\
(4.71 \pm 0.11)\end{array}$ & 0.007 & -0.495 & 0.510 & 0.977 \\
\hline
\end{tabular}

Table 8: Variations in the measurement of inter die distance (KL) when using $0.5 \mathrm{~mm}, 1 \mathrm{~mm}$, and $1.5 \mathrm{~mm}$ spacers.

\begin{tabular}{|c|c|c|c|c|c|}
\hline \multirow{2}{*}{ Inter-die distance } & Comparison Group & \multirow{2}{*}{ Mean Diff } & \multicolumn{2}{|c|}{$\mathbf{9 5 \%}$ Confidence Interval } & \multirow{2}{*}{ P value } \\
\cline { 1 - 5 } $\begin{array}{c}\text { KL dimension when using } \\
0.5 \mathrm{~mm} \text { spacer (Group II) } \\
(21.40 \pm 0.08)\end{array}$ & $\begin{array}{c}\text { Group III (1mm) } \\
(21.39 \pm 0.07)\end{array}$ & 0.005 & -0.047 & 0.057 & 0.849 \\
\hline $\begin{array}{c}\text { Group IV (1.5 mm) } \\
(21.41 \pm 0.08)\end{array}$ & -0.008 & -0.061 & 0.044 & 0.743 \\
\hline $\begin{array}{c}\text { Group III (1mm) } \\
(21.39 \pm 0.07)\end{array}$ & $\begin{array}{c}\text { Group IV (1.5mm) } \\
(21.41 \pm 0.08)\end{array}$ & -0.013 & -0.066 & 0.039 & 0.604 \\
\hline
\end{tabular}

*statistically significant.

\section{Discussion}

For obtaining good quality impression, selection of appropriate impression materials and impression techniques are important. The advancement in material science and development of different techniques have contributed to achieve this requirements. ${ }^{4}$ There are several studies in different dental literatures about the effect of material and impression technique on the accuracy of cast and final restorations. Some authors showed that the cast accuracy is affected more by the used impression technique than by the chosen material. ${ }^{5-7}$ Other researchers reported that the impression technique does not affect the dimensional accuracy. ${ }^{7-9}$ Craig had stated that impression materials have improved upto such an extent that accuracy may be controlled more with technique than by material itself., ${ }^{9,10}$ Hung et al and Idris et al investigated the importance 
of techniques and reported that impression accuracy is not technique dependent. $(7,8)$

Whereas Nissan et al reported that two step technique is more accurate impression technique as there is uniform wash space for the light body material to polymerize. Furthermore, the wash thickness is an essential factor that influences the accuracy of elastomeric impression materials. ${ }^{11,12}$

Among them elastomeric impression material is the most commonly used. According to American National Standards Institute (ANSI)/American Dental Association (ADA) specification \#19, elastomeric impression materials must be able to reproduce fine detail of $25 \mu \mathrm{m}$ or less for which polyvinyl siloxane impression materials are the best. ${ }^{13}$ Hence, dimensional accuracy of cast obtained from polyvinyl siloxane impression made by single step putty wash technique was more dimensionally accurate mesio-distally, bucco-lingually and in inter-die dimensions except in cervico-occlusal dimension.

This in-vitro study compared the dimensional accuracy of cast obtained from different impression techniques using spacers does not simulate the exact clinical scenario. Single step technique showed more accurate cast. The use of a standard model simulating tooth preparation rather than actual tooth preparation in patients contributes to the limitations of the present study. Therefore further investigations are necessary to evaluate the accuracy of cast obtained with different impression technique using spacer under closely simulated clinical conditions.

\section{Conclusions}

Cast obtained from polyvinyl siloxane impression made by single step putty- wash technique was more accurate dimensionally. Among two-step putty wash technique, $1.5 \mathrm{~mm}$ spacer thickness was more accurate dimensionally and $0.5 \mathrm{~mm}$ spacer thickness was least accurate.

\section{Acknowledgements}

Prof. Dr. Suraj Ram Bhakta Mathema

All the faculty members

Dipendra Dental Art Lab

Dr. Reshu Agrawal

\section{REFERENCES}

1. Koch R, Natd R, Walter MH, Habile MD, Quaas $\mathrm{S}$, Dentc M. Randomized controlled clinical study on the accuracy of two-stage putty-andwash impression materials. 2009;22:296-302

2. Babita Y, Neha C, Nazish B, Tated G, Pranit K. Impressions in fixed partial denture: A review update. European Journal of Experimental Biology. 2015;5(12):1-5.

3. Saunders W, Sharkey S, Smith GM, Taylor W. Effect of impression tray design and impression technique upon the accuracy of stone casts produced from a putty-wash polyvinyl siloxane impression material. Journal of dentistry. 1991;19(5):283-9.

4. Franco EB, da Cunha LF, Herrera FS, Benetti AR. Accuracy of single-step versus 2-step double-mix impression technique. ISRN dentistry. 2011;11(5):9.

5. Nissan J, Laufer B-Z, Brosh T, Assif D, Maurice T. Accuracy of three polyvinyl siloxane puttywash impression techniques. The Journal of prosthetic dentistry. 2000;83(2):161-5.

6. Caputi S, Varvara G. Dimensional accuracy of resultant casts made by a monophase, onestep and two-step, and a novel two-step putty/ light-body impression technique: an in vitro study. The Journal of prosthetic dentistry. 2008;99(4):274-81.

7. Idris B, Houston F, Claffey N. Comparison of the dimensional accuracy of one-and two-step techniques with the use of putty/wash addition silicone impression materials. The Journal of prosthetic dentistry. 1995;74(5):535-41.

8. Hung SH, Purk JH, Tira DE, Eick JD. Accuracy of one-step versus two-step putty wash addition silicone impression technique. The Journal of prosthetic dentistry. 1992;67(5):583-9. 
9. Johnson GH, Craig RG. Accuracy of addition silicones as a function of technique. The Journal of prosthetic dentistry. 1986;55(2):197-203.

10. Craig R. Review of dental impression materials. Advances in dental research. 1988;2(1):51-64.

11. Eames W, Wallace S, Suway N, Rogers L. Accuracy and dimensional stability of elastomeric impression materials. The Journal of prosthetic dentistry. 1979;42(2):159-62.
12. Takahashi H, Finger WJ. Effects of the setting stage on the accuracy of double-mix impressions made with addition-curing silicone. The Journal of prosthetic dentistry. 1994;72(1):78-84.

13. Ragain JC, Grosko ML, Raj M, Ryan TN, Johnston WM. Detail reproduction, contact angles, and die hardness of elastomeric impression and gypsum die material combinations. International Journal of Prosthodontics. 2000;13(3). 